\title{
ESTIMATION OF VARIABILITY ANALYSIS PARAMETERS FOR MAJOR GROWTH AND FLOWERING TRAITS OF Lilium leichtlinii var. maximowiczii GERMPLASM
}

\author{
Rameshwar Rai ${ }^{1,2}$ (D), Viet Yen Nguyen ${ }^{1}$, Jong Hwa Kim ${ }^{1,2^{*}}$ (iD \\ ${ }^{1}$ College of Agriculture and Life Sciences, Department of Horticulture, Kangwon National University(KNU), Chuncheon 24341, Korea \\ ${ }^{2}$ Oriental Bio-herb Research Institute, Kangwon National University, Chuncheon 24341, Korea \\ Received - July 12, 2021; Revision - August 19, 2021; Accepted - August 29, 2021 \\ Available Online -August 30, 2021 \\ DOI: http://dx.doi.org/10.18006/2021.9(4).457.463
}

\section{KEYWORDS \\ Lilium leichtlinii var. \\ maximowiczii \\ Analysis of Variance (ANOVA) \\ Germplasm \\ Heritability \\ Variability parameters}

\begin{abstract}
This experiment was carried out to evaluate the Lilium leichtlinii var maximowiczii germplasm collected from the different natural habitats from all over Korea. In total 30 accessions were studied for nine traits viz. plant height, leaf length, leaf width, the numbers of flowers, flower diameter, length of outer tepal, width of outer tepal, the number of leaf burn, and days to flowering in randomized block design with three replications. The ANOVA revealed highly significant variability prevailing among the investigated genotypes for almost all studied traits (except leaf width). The higher estimated value of GCV, PCV, heritability $\left(\mathrm{H}^{2}\right)$, and genetic advance as percent of the mean was obtained for the number of flowers and leaf burn. The moderate to high GCV and PCV coupled with higher heritability estimates $\left(\mathrm{H}^{2}\right)$ and GAM were found for plant height and flower diameter. Progeny selection would be effective as the prevalence of additive gene effect for these traits. Besides, leaf width, leaf length, length of outer tepal, the width of outer tepal, and days to flowering traits were possessed moderate to low GCV and PCV value coupled with the moderate value of heritability estimate with the low level of GAM proved to be the prevalence of non-additive genetic effect thereby indicating the necessity of alternative breeding approach for these traits improvement and breeding scheme. For the former group of traits breeding hybridization and selection would be an effective method, and primarily mean performance of these traits would be very handy for the decision of selection.
\end{abstract}

* Corresponding author

E-mail: jonghwa@ kangwon.ac.kr (Jong-Hwa Kim)

Peer review under responsibility of Journal of Experimental Biology and Agricultural Sciences.

Production and Hosting by Horizon Publisher India [HPI] (http://www.horizonpublisherindia.in/).

All rights reserved.
All the articles published by Journal of Experimental Biology and Agricultural Sciences are licensed under a Creative Commons Attribution-NonCommercial 4.0 International License Based on a work at www.jebas.org.

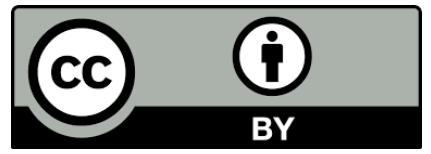




\section{Introduction}

The genus Lily belongs to the family Liliaceae includes more than 110 species throughout the world, out of which 50-60 species are being cultivated in Asia, 24 species are being exploited in North America, and 12 species are exploiting in Europe (Dhiman et al., 2018). In the context of Asia, the East Asian region especially Japan, Korea, and China are thought to be the native of the many wild lily species (Mc Rae, 1998; Gao \& Gao, 2016). The southwest and north parts of China are taken as natural habitats of more than 55 species of wild lily, and it is believed to be the center of the diversity of Lilium species (De Jong, 1974). Furthermore, Korea is thought to be another center of genetic diversity of Lilium in Asia due to the availability of diverse geographical and climatic characteristics, including temperate and warm climatic pockets, and to date total of 15 wild species have been exploited (Kim, 2008; Lucidos et al., 2013). Further, till now 15 wild lily species have been recorded so far in the East Asian region, and seven species belong to the Sinomartagon section i.e. L. amabile, $L$. callosum, L. cernuum, L. concolor, L. lancifolium, and $L$. leichtlinii var maximowiczii. Based on morphological and cytological characteristics, L. leichtlinii var maximowiczii is thought to be closely related to the origin of triploid L. lancifolium (Tiger-lily) (Nguyen et al., 2015). Its wide distribution comprised Japan, Korea, Manchuria, Northern China, and Ussuri in Russia (Nguyen et al., 2015), and it is an endemic lily in Korea. Earlier $L$. leichtlinii var maximowiczii was thought to be diploid like $L$. lancifolium but later on, it has also proved to be diploid-triploid complex species (Kim et al., 2006; Nguyen et al., 2015; Nguyen et al., 2016). According to Wilson (1925), tiger lily (L. lancifolium) can be distinguished from $L$. leichtlinii var maximowiczii which possesses a stoloniferous bulb-bearing underground stem and the complete absence of bulbils on the leaf-axils. Lighty (1968) had explored Lilium populations in South Korea and suggested limited distribution of L. leichtlinii var maximowiczii and it was reported only from Gangwon do province. Jeong (1991) had collected $L$. leichtlinii var maximowiczii specimens in Korea from Sokeumkang (Gangneung city), Goonbukmyun of Ockcheongun and Miryang of Kyangsangnam-do and other botanists had collected specimens from Kumo-do, the southernmost part of Korea to Gangwon do, the northernmost part of Korea, though some specimens were misidentified (KBIS, 2013). Kim et al. (2016) had reported that L.leichtlinii var maximowiczii plants grow in very scattered populations and are distributed in steep mountain ranges of Chungcheongbuk do, Gyeonggi-do, and Gangwon-do provinces of South Korea. Noda (1966), Noda (1974), and Noda (1986), hypothesized that sterile triploids of $L$. lancifolium might have originated from L. leichtlinii var maximowiczii. In this context, previous studies have been reported a favorable argument regarding the origin of triploid $L$ lancifolium that they had surveyed 30 Korean islands since 1997 but never identified
L.leichtlinii var maximowiczii on these islands (Kim et al., 2004, 2005, 2006) where only diploids Lilium lancifolium are distributed. The triploids plants are more common than diploid plants in L.leichtlinii var maximowiczii populations, but both triploids and diploids populations have possessed only one cytotype while analysis was carried out through conventional chromosome analysis (Kim et al., 2016). L. leichtlinii var maximowiczii germplasm has been collected, and every accession has registered at the germplasm reservation center, gene bank at rural development administration (RDA). Germplasm evaluation deserves prime importance for any breeding scheme as previously introduced L.leichtlinii var maximowiczii comprised of both diploid and tripod. These varieties can be distinguished based on morphology. This study's objective is to assess variability for major growth and flowering traits of $30 \mathrm{~L}$. leichtlinii var maximowiczii, thereby understanding the breeding potentiality of that germplasm for population improvement.

\section{Materials and Methods}

\subsection{Plant material}

The plant materials used for this study consisted of 30 genotypes of the L.leichtlinii var. maximowiczii (Table 1) received from the floricultural breeding lab under the department of horticulture, Kangwon National University (KNU). These genotypes were collected from the different habitats especially forest areas of different locations of South Korea and officially registered in the germplasm reservation center of Rural Development Admiration (RDA), and other government organizations of the Gangwon Province, providing IT number and GWL number on the behalf of oriental bio herb research institute and was used continuously as germplasm for further breeding and research scheme.

\subsection{Field layout and Experimental setup}

The commercial bulbs of all 30 genotypes as standing crops were obtained at KNU main research farm. The whole field was laid out as a block consisting of 20 beds, and each bed measured $30 \mathrm{~m}$ long and $1.2 \mathrm{~m}$ wide. The space in between the bed was $0.6-0.75 \mathrm{~m}$ for intercultural operation viz. weeding, herbicide, insecticide, fertilizer application, plowing, etc. The bulbs were transplanted plant to plant and row to row equidistance of $12.5 \mathrm{~cm}$. The bulbs were grown in the field as randomized block design (RBD) with three replications.

\subsection{Morphological observation and sampling}

The morphological observation of 9 important traits of $30 \mathrm{~L}$. leichtlinii var maximowiczii genotypes were measured and collected at the KNU main research farm growing site during the flowering season from the first week of June 2020 to the last week 
of July 2020. Since the limited germplasm was collected and maintained in the farm with three replications, each replication represented three plants. For morphological observation, every single plant was taken as a sample, eliminating those with similar morphological appearances. The morphological measurements were taken by following the guidelines of lily register checklists given by Matthews (2007).

\subsection{Statistical analysis}

The raw data obtained by observing the morphology of all 30 genotypes for nine studied characteristics were first processed and prepared using MS-excel 2013 and analyzed the least significant difference, and further analysis of variability parameters was carried out using the TNAUSTAT statistical packages. The

Table 1 Lists of genotypes designation, its special characteristics and resource center of L. leichtlinii var. maximowiczii genotypes

\begin{tabular}{|c|c|c|c|}
\hline S.N. & Genotypes Designation & Special remarks & Resource \\
\hline 1 & IT 282830 & Early flowering, Middle plant height, Botrytis infestation $10.1 \sim 20 \%$. & \multirow{30}{*}{$\begin{array}{c}\text { Oriental bio-herb } \\
\text { research Institute } \\
\text { / Floricultural } \\
\text { breeding lab., } \\
\text { KNU }\end{array}$} \\
\hline 2 & IT 283143 & Intermediate flowering habit and plant height, Botrytis infestation 5.1 10\%. & \\
\hline 3 & GWL 1522 & Tall, early flowering, Botrytis infestation $1.1 \sim 5 \%$. & \\
\hline 4 & IT 283142 & Intermediate plant height and flowering, and botrytis infestation $1.1 \sim 5 \%$. & \\
\hline 5 & IT 283183 & Early flowering and middle plant height, and botrytis infestation $1.1 \sim 5 \%$. & \\
\hline 6 & IT 283147 & Tall and intermediate flowering habit, and botrytis infestation 5.1 10\%. & \\
\hline 7 & IT 283148 & Intermediate flowering and plant height, and free of botrytis infestation. & \\
\hline 8 & IT 283146 & Tall and early flowering habit, and free of botrytis infestation. & \\
\hline 9 & IT 283144 & Early flowering and middle plant height, and free of botrytis infestation. & \\
\hline 10 & IT 283151 & Tall and middle plant height, and free of botrytis infestation. & \\
\hline 11 & GWL 1300 & Early flowering and middle plant height, and botrytis infestation $1.1 \sim 5 \%$. & \\
\hline 12 & IT 282927 & Middle to tall and late flowering, and botrytis infestation $1.1 \sim 5 \%$ & \\
\hline 13 & IT 283134 & Middle-Tall, late flowering, and botrytis infestation $1.1 \sim 5 \%$ & \\
\hline 14 & IT 283141 & Tall and late flowering, and free of botrytis infestation. & \\
\hline 15 & IT 283152 & Very tall and intermediate flowering habit, and botrytis infestation $1.1 \sim 5 \%$. & \\
\hline 16 & GWL 1527 (214 Yanggu) & Short plant height but late flowering, and botrytis infestation $1.1 \sim 5 \%$. & \\
\hline 17 & IT 282827 & Very tall and late flowering, and botrytis infestation $<1 \%$. & \\
\hline 18 & IT 283125 & Short to middle and late flowering, and botrytis infestation $<1 \%$. & \\
\hline 19 & IT 283128 & Very tall and late flowering, and free of botrytis infestation. & \\
\hline 20 & IT 283129 & Tall and late flowering, and botrytis infestation $<1 \%$. & \\
\hline 21 & IT 283140 & Very tall but intermediate flowering habit, and botrytis infestation $<3 \%$ & \\
\hline 22 & IT 283134 & $\begin{array}{l}\text { Middle plant height but middle to late flowering habit, and botrytis infestation } \\
5.1 \sim 10 \% \text {. }\end{array}$ & \\
\hline 23 & GWL 1426 (517 Sangnam) & Very tall but middle to late flowering, and botrytis infestation $1.1 \sim 5 \%$. & \\
\hline 24 & $\begin{array}{c}\text { GWL } 1477 \\
(5393 \times \text { Jungnali })\end{array}$ & Middle to tall, early flowering, and botrytis infestation $1.1 \sim 5 \%$. & \\
\hline 25 & $\begin{array}{c}\text { GWL } 1477 \\
(20135332 \times \text { Jungnali) }\end{array}$ & Taller but early flowering, and botrytis infestation 5.1 10\%. & \\
\hline 26 & IT 283139 & Middle-Tall, intermediate flowering habit, and botrytis infestation $5.1 \sim 10 \%$. & \\
\hline 27 & IT 283131 & Very tall but early flowering, and botrytis infestation $10.1 \sim 20 \%$. & \\
\hline 28 & IT 283154 & Tall and intermediate flowering habit, free of botrytis infestation. & \\
\hline 29 & IT 283138 & Shorter but late flowering, and botrytis infestation $10.1 \sim 20 \%$. & \\
\hline 30 & IT 283127 & ate plant height and flowering time, and botrytis infestation $1.1 \sim 5 \%$. & \\
\hline
\end{tabular}

Journal of Experimental Biology and Agricultural Sciences

http://www.jebas.org 
ANOVA analysis, $\mathrm{F}$ test, and other variance components viz. PCV, GCV, ECV, heritability (H2), GA, and GAM were estimated by adopting the plant breeding general tools in a randomized block design (RBD); variability analysis of TNAUSTAT statistical package. Likewise, the DMRT (Duncan's multiple range test) was estimated at the $5 \%$ significance level for separating the estimated means of all the treatments following the DMRT comparison tools under the general designs head of the TNAUSTAT statistical package (Manivannan, 2014). The genotypic, phenotypic, environmental, and consecutive components variation were estimated using the formula and methods given by Burton \& Devane (1953). In addition, heritability $\left(\mathrm{H}^{2}\right)$, genetic advance, and genetic advance as percentages of mean were estimated by adopting the formula and method given by Allard (1960).

\section{Results and Discussion}

3.1 Analysis of variance (ANOVA) and other variability parameters GCV, PCV, and ECV

The estimated value of analysis of variance (ANOVA) demonstrated that almost all investigated traits (besides leaf width) of L.leichtlinii var maximowiczii were significantly different among the 30 studied genotypes at $1 \%$ level of significance (Table 2). This provides the validity of the experiment being conducted; the existence of variability's is the raw materials for the breeders, biologists, and geneticists which are the foundation for the execution of the future breeding scheme. Other coefficients of variance components GCV (genotypic coefficients of variation), PCV (phenotypic coefficients of variation), ECV (environmental coefficients of variation) with the addition of genetic advance and genetic advance as percent of the mean (GAM) were presented in table 2. There was a prevalence of environmental effect on the expression of the studied traits as observed higher phenotypic coefficients variation value than genotypic coefficients of variation (Table 2). As observed in the current study, the estimated value of PCV and GCV for the investigated traits in this study was ranged between 5.32 and 4.71 for days to flowering and 82.08 and 59.41 for leaf burn, respectively, thereby indicating the prevalence of substantial broad-based genetic variability ability among the studied genotypes. Based on the classification provided by Deshmukh et al. (1986), higher GCV and PCV for the number of leaf burn and the number of flowers have been reported in this study; herby indicating that these traits of the studied genotypes are performing outstanding, and there is a practical possibility for improvement through considering these traits during selection and hybridization. Likewise, the estimated GCV and PCV values demonstrated that plant height and flower diameter possessed a moderate value for this parameter, meaning acceptable improvement might be obtained through selecting these traits (Table 2). In addition, remaining traits including leaf length, leaf width, length of OT, and width of OT had demonstrated the combination of lower GCV value and moderate PCV value while for the days to flowering had possessed the combination of both GCV and PCV value low, thereby indicated for this traits that there was existing low level of magnitude of heritable genetic factor to the next generation, non-additive gene action was playing the vital role for these traits.

\subsection{The mean performances of the investigated nine traits}

The mean performance of all 30 genotypes for the studied traits viz. plant height, leaf length, leaf width, number of flowers, flower diameter, length of outer tepal (OT), the width of OT, number of leaf burn, and days to flowering are given in Table 3. The mean performance table demonstrated huge variability for the studied traits among the investigated genotypes. The tallest genotype goes for GWL 1426 (517 Sangnam) with $127.7 \mathrm{~cm}$ average plant height,

Table 2 ANOVA and estimation of variability parameters for growth and flowering traits in L. leichtlinii var. maximowiczii genotypes

\begin{tabular}{|c|c|c|c|c|c|c|c|c|c|c|}
\hline $\begin{array}{c}\text { Traits } \\
\text { / Parameter }\end{array}$ & G. Mean \pm SEM & LSD $(5 \%)$ & CV (\%) & $\mathrm{F}$ test & PCV (\%) & GCV (\%) & $\mathrm{ECV}(\%)$ & $\mathrm{H}^{2}(\%)$ & GA & GAM (\%) \\
\hline Plant height $(\mathrm{cm})$ & $101.2 \pm 1.7$ & 20.10 & 11.02 & $* *$ & 15.98 & 11.57 & 11.02 & 52.45 & 65.97 & 17.26 \\
\hline Leaf length & $13.5 \pm 0.2$ & 2.19 & 8.92 & $* *$ & 11.88 & 7.85 & 8.92 & 43.66 & 5.94 & 10.69 \\
\hline Leaf width & $1.5 \pm 0.0$ & 0.29 & 13.53 & $\mathrm{~ns}$ & 14.26 & 4.50 & 13.53 & 9.96 & 0.22 & 2.93 \\
\hline No. of flowers & $4.9 \pm 0.3$ & 3.52 & 39.35 & $* *$ & 52.00 & 33.99 & 39.35 & 42.72 & 9.23 & 45.77 \\
\hline Flower diameter & $39.0 \pm 0.9$ & 11.70 & 16.31 & $* *$ & 21.99 & 14.75 & 16.31 & 44.98 & 32.26 & 20.38 \\
\hline Length of OT & $8.3 \pm 0.1$ & 0.93 & 6.24 & $* *$ & 8.24 & 5.37 & 6.24 & 42.53 & 2.47 & 7.22 \\
\hline Width of OT & $1.9 \pm 0.0$ & 0.30 & 8.84 & $* *$ & 11.05 & 6.63 & 8.84 & 35.98 & 0.69 & 8.19 \\
\hline Leaf burn (No.) & $5.9 \pm 0.5$ & 6.56 & 56.63 & $* *$ & 82.08 & 59.41 & 56.63 & 52.39 & 19.60 & 88.58 \\
\hline Days to flowering & $97.1 \pm 0.6$ & 7.40 & 2.46 & $* *$ & 5.32 & 4.71 & 2.46 & 78.54 & 21.19 & 8.60 \\
\hline
\end{tabular}

Journal of Experimental Biology and Agricultural Sciences

http://www.jebas.org 
while the shortest genotype was recorded for GWL 1527 (214 length of 11.3cm. Likewise, the broadest and narrowest leaves Yanggu) with $71.0 \mathrm{~cm}$ average plant height. Most extended leaves were found for genotypes IT 283142 and IT 283125 , with the were measured for IT 283134 with an average leaf length of average leaf width of $1.77 \mathrm{~cm}$ and $1.20 \mathrm{~cm}$, respectively. The $16.4 \mathrm{~cm}$, while shortest leaves were recorded for the genotypes IT highest numbers of the flower were found for genotype IT 283151, 282830 and GWL 1527 (214 Yanggu) jointly with the average leaf with an average number of flowers of 11.3.

Table 3 The mean performance for major growth and flowering traits of L. leichtlinii var. maximowiczii genotypes

\begin{tabular}{|c|c|c|c|c|c|c|c|c|c|}
\hline Traits /Genotypes & $\begin{array}{l}\text { Plant } \\
\text { height }\end{array}$ & $\begin{array}{l}\text { Leaf } \\
\text { length }\end{array}$ & $\begin{array}{l}\text { Leaf } \\
\text { width }\end{array}$ & $\begin{array}{l}\text { No. of } \\
\text { flowers }\end{array}$ & $\begin{array}{l}\text { Flower } \\
\text { diameter }\end{array}$ & $\begin{array}{l}\text { Length } \\
\text { of OT }\end{array}$ & $\begin{array}{l}\text { Width } \\
\text { of OT }\end{array}$ & $\begin{array}{l}\text { Leaf burn } \\
\text { (No.) }\end{array}$ & $\begin{array}{l}\text { Days to } \\
\text { flowering }\end{array}$ \\
\hline IT 282830 & $89.3^{\mathrm{fg}}$ & $11.3^{\mathrm{h}}$ & $1.43^{\mathrm{ab}}$ & $4.3^{\mathrm{de}}$ & $34.88^{\mathrm{bc}}$ & $7.1^{\mathrm{eg}}$ & $1.73^{\mathrm{de}}$ & $3.3 \mathrm{ef}$ & $92.7^{\mathrm{kl}}$ \\
\hline IT 283143 & $102.3^{\mathrm{bc}}$ & $11.6^{\mathrm{fg}}$ & $1.37^{\mathrm{bc}}$ & $4.0^{\mathrm{de}}$ & $46.58^{\mathrm{ab}}$ & $8.6^{\mathrm{ab}}$ & $2.13^{\mathrm{ab}}$ & $2.3^{\mathrm{fg}}$ & $98.3^{\text {ef }}$ \\
\hline GWL 1522 & $107.0^{\mathrm{ab}}$ & $13.6^{\mathrm{bc}}$ & $1.47^{\mathrm{ab}}$ & $4.0^{\mathrm{de}}$ & $34.64^{\mathrm{bc}}$ & $8.0^{\text {cd }}$ & $1.83^{\mathrm{bc}}$ & $4.3^{\mathrm{ef}}$ & $88.0^{\mathrm{p}}$ \\
\hline IT 283142 & $106.3^{\mathrm{ab}}$ & $14.1^{\mathrm{ab}}$ & $1.77^{\mathrm{a}}$ & $5.0^{\mathrm{cd}}$ & $38.19^{\mathrm{ab}}$ & $8.5^{\mathrm{ab}}$ & $2.00^{\mathrm{ab}}$ & $12.3^{\mathrm{ab}}$ & $96.3^{\mathrm{fg}}$ \\
\hline IT 283183 & $95.67^{\mathrm{de}}$ & $12.6^{\mathrm{de}}$ & $1.43^{\mathrm{ab}}$ & $3.3^{\mathrm{e}}$ & $33.52^{\text {cd }}$ & $8.1^{\mathrm{bc}}$ & $1.67^{\mathrm{ef}}$ & $9.3^{\mathrm{bc}}$ & $90.3^{\mathrm{no}}$ \\
\hline IT 283147 & $112^{\mathrm{ab}}$ & $14.1^{\mathrm{ab}}$ & $1.67^{\mathrm{ab}}$ & $5.0^{\mathrm{cd}}$ & $18.45^{\mathrm{g}}$ & $8.5^{\mathrm{ab}}$ & $2.13^{\mathrm{ab}}$ & $6.3^{\text {cd }}$ & $93.0^{\mathrm{jk}}$ \\
\hline IT 283148 & $89.57^{\mathrm{fg}}$ & $12.5^{\mathrm{ef}}$ & $1.53^{\mathrm{ab}}$ & $3.0^{\mathrm{e}}$ & $40.73^{\mathrm{ab}}$ & $7.9^{\text {ce }}$ & $1.80^{\mathrm{bc}}$ & $2.7^{\mathrm{fg}}$ & $92.0^{\mathrm{lm}}$ \\
\hline IT 283146 & $104.33^{\mathrm{bc}}$ & $13.8^{\mathrm{bc}}$ & $1.53^{\mathrm{ab}}$ & $6.0^{\mathrm{bc}}$ & $37.59^{\mathrm{ab}}$ & $8.0^{\mathrm{cd}}$ & $1.90^{\mathrm{ab}}$ & $3.3^{\mathrm{ef}}$ & $91.3^{\mathrm{mn}}$ \\
\hline IT 283144 & $98.33^{\mathrm{cd}}$ & $12.2^{\text {ef }}$ & $1.53^{\mathrm{ab}}$ & $4.0^{\mathrm{de}}$ & $38.03^{\mathrm{ab}}$ & $8.0^{\text {cd }}$ & $1.63^{\text {fh }}$ & $2.7^{\mathrm{fg}}$ & $90.7^{\mathrm{no}}$ \\
\hline IT 283151 & $108.33^{\mathrm{ab}}$ & $15.8^{\mathrm{ab}}$ & $1.53^{\mathrm{ab}}$ & $11.3^{\mathrm{a}}$ & $48.33^{\mathrm{a}}$ & $8.3^{\mathrm{ab}}$ & $2.10^{\mathrm{ab}}$ & $1.3^{\mathrm{gh}}$ & $95.3^{\text {gh }}$ \\
\hline GWL 1300 & $100.67^{\mathrm{bc}}$ & $13.1^{\text {cd }}$ & $1.40^{\mathrm{ab}}$ & $3.0^{\mathrm{e}}$ & $21.80^{\mathrm{fg}}$ & $8.7^{\mathrm{ab}}$ & $1.93^{\mathrm{ab}}$ & $3.3^{\text {ef }}$ & $89.7^{\text {op }}$ \\
\hline IT 282927 & $98.33^{\text {cd }}$ & $12.6^{\mathrm{de}}$ & $1.60^{\mathrm{ab}}$ & $3.3^{\mathrm{e}}$ & $41.83^{\mathrm{ab}}$ & $8.2^{\mathrm{ab}}$ & $1.93^{\mathrm{ab}}$ & $17.3^{\mathrm{a}}$ & $107.0^{\mathrm{a}}$ \\
\hline IT 283134 & $93.3^{\mathrm{de}}$ & $15.2^{\mathrm{ab}}$ & $1.63^{\mathrm{ab}}$ & $5.6^{\mathrm{bc}}$ & $39.67^{\mathrm{ab}}$ & $8.1^{\mathrm{bc}}$ & $2.07^{\mathrm{ab}}$ & $4.7^{\mathrm{de}}$ & $103.0^{\mathrm{ab}}$ \\
\hline IT 283141 & $106.0^{\mathrm{bc}}$ & $13.7^{\mathrm{bc}}$ & $1.40^{\mathrm{ab}}$ & $4.0^{\mathrm{de}}$ & $40.00^{\mathrm{ab}}$ & $8.5^{\mathrm{ab}}$ & $1.97^{\mathrm{ab}}$ & $3.3^{\mathrm{ef}}$ & $100.0^{\text {cd }}$ \\
\hline IT 283152 & $114.7^{\mathrm{ab}}$ & $13.5^{\mathrm{bc}}$ & $1.40^{\mathrm{ab}}$ & $5.0^{\text {cd }}$ & $41.67^{\mathrm{ab}}$ & $8.7^{\mathrm{ab}}$ & $2.00^{\mathrm{ab}}$ & $0.3^{\mathrm{h}}$ & $97.3^{\mathrm{fg}}$ \\
\hline $\begin{array}{c}\text { GWL 1527 } \\
\text { (214 Yanggu) }\end{array}$ & $71.0^{\mathrm{i}}$ & $11.3^{\mathrm{h}}$ & $1.27^{\mathrm{cd}}$ & $3.7^{\mathrm{de}}$ & $31.67^{\mathrm{de}}$ & $6.7^{\mathrm{h}}$ & $1.77^{\mathrm{cd}}$ & $6.0^{\mathrm{de}}$ & $100.3^{\mathrm{cd}}$ \\
\hline IT 282827 & $122.7^{\mathrm{ab}}$ & $14.4^{\mathrm{ab}}$ & $1.33^{\mathrm{bc}}$ & $4.3^{\mathrm{de}}$ & $40.85^{\mathrm{ab}}$ & $8.5^{\mathrm{ab}}$ & $1.87^{\mathrm{bc}}$ & $4.3^{\mathrm{eff}}$ & $100.3^{\text {cd }}$ \\
\hline IT 283125 & $79.3^{\text {gh }}$ & $11.5^{\text {gh }}$ & $1.20^{\mathrm{e}}$ & $2.7^{\mathrm{e}}$ & $31.50^{\mathrm{ef}}$ & $7.9^{\text {cd }}$ & $1.73^{\mathrm{de}}$ & $9.7^{\mathrm{bc}}$ & $105.0^{\mathrm{ab}}$ \\
\hline IT 283128 & $118.7^{\mathrm{ab}}$ & $14.5^{\mathrm{ab}}$ & $1.23^{\mathrm{de}}$ & $9.0^{\mathrm{ab}}$ & $41.70^{\mathrm{ab}}$ & $8.7^{\mathrm{ab}}$ & $1.97^{\mathrm{ab}}$ & $8.3^{\mathrm{bc}}$ & $103.7^{\mathrm{ab}}$ \\
\hline IT 283129 & $100.3^{\text {cd }}$ & $13.1^{\mathrm{cd}}$ & $1.33^{\mathrm{bc}}$ & $4.0^{\mathrm{de}}$ & $39.00^{\mathrm{ab}}$ & $8.0^{\text {cd }}$ & $1.83^{\mathrm{bc}}$ & $2.0^{\mathrm{fg}}$ & $102.3^{\mathrm{bc}}$ \\
\hline IT 283140 & $113.7^{\mathrm{ab}}$ & $14.5^{\mathrm{ab}}$ & $1.43^{\mathrm{ab}}$ & $5.6^{\mathrm{bc}}$ & $36.33^{\mathrm{ab}}$ & $8.4^{\mathrm{ab}}$ & $1.97^{\mathrm{ab}}$ & $6.0^{\mathrm{de}}$ & $99.7^{\mathrm{cd}}$ \\
\hline IT 283134 & $90.0^{\text {ef }}$ & $16.4^{\mathrm{a}}$ & $1.60^{\mathrm{ab}}$ & $6.0^{\mathrm{bc}}$ & $42.00^{\mathrm{ab}}$ & $8.7^{\mathrm{ab}}$ & $2.07^{\mathrm{ab}}$ & $6.0^{\mathrm{de}}$ & $99.0^{\mathrm{de}}$ \\
\hline $\begin{array}{c}\text { GWL } 1426 \\
\text { (517 Sangnam) }\end{array}$ & $127.7^{\mathrm{a}}$ & $14.3^{\mathrm{ab}}$ & $1.50^{\mathrm{ab}}$ & $7.3^{\mathrm{bc}}$ & $43.07^{\mathrm{ab}}$ & $9.2^{\mathrm{a}}$ & $1.93^{\mathrm{ab}}$ & $3.7^{\mathrm{ef}}$ & $99.7^{\text {cd }}$ \\
\hline $\begin{array}{c}\text { GWL } 1477 \\
(5393 \times \text { Jungnali) }\end{array}$ & $95.0^{\mathrm{de}}$ & $13.8^{\mathrm{bc}}$ & $1.50^{\mathrm{ab}}$ & $5.7^{\mathrm{bc}}$ & $46.33^{\mathrm{ab}}$ & $8.7^{\mathrm{ab}}$ & $2.13^{\mathrm{ab}}$ & $5.7^{\mathrm{de}}$ & $94.3^{\mathrm{ij}}$ \\
\hline GWL 1477 (2013 $5332 \times$ Jungnali) & $106.0^{\mathrm{bc}}$ & $13.9^{\mathrm{bc}}$ & $1.63^{\mathrm{ab}}$ & $3.7^{\mathrm{de}}$ & $45.33^{\mathrm{ab}}$ & $8.6^{\mathrm{ab}}$ & $2.07^{\mathrm{ab}}$ & $6.3^{\mathrm{cd}}$ & $95.7^{\mathrm{fg}}$ \\
\hline IT 283139 & $105.0^{\mathrm{bc}}$ & $14.0^{\mathrm{bc}}$ & $1.40^{\mathrm{ab}}$ & $4.0^{\mathrm{de}}$ & $44.33^{\mathrm{ab}}$ & $7.5^{\mathrm{de}}$ & $1.60^{\mathrm{h}}$ & $6.0^{\mathrm{de}}$ & $97.3^{\mathrm{fg}}$ \\
\hline IT 283131 & $113.3^{\mathrm{ab}}$ & $13.3^{\mathrm{cd}}$ & $1.67^{\mathrm{ab}}$ & $5.0^{\mathrm{cd}}$ & $44.67^{\mathrm{ab}}$ & $8.4^{\mathrm{ab}}$ & $2.10^{\mathrm{ab}}$ & $11.0^{\mathrm{bc}}$ & $94.7^{\text {hi }}$ \\
\hline IT 283154 & $105.0^{\mathrm{bc}}$ & $15.0^{\mathrm{ab}}$ & $1.50^{\mathrm{ab}}$ & $8.3^{\mathrm{ab}}$ & $47.67^{\mathrm{a}}$ & $9.1^{\mathrm{ab}}$ & $2.23^{\mathrm{a}}$ & $2.0^{\mathrm{fg}}$ & $97.0^{\mathrm{fg}}$ \\
\hline IT 283138 & $72.7^{\mathrm{hi}}$ & $12.9^{\text {cd }}$ & $1.47^{\mathrm{ab}}$ & $2.3^{\mathrm{e}}$ & $36.73^{\mathrm{ab}}$ & $7.8^{\mathrm{cd}}$ & $2.00^{\mathrm{ab}}$ & $14.3^{\mathrm{ab}}$ & $100.3^{\text {cd }}$ \\
\hline IT 283127 & $88.7^{\mathrm{fg}}$ & $12.9^{\mathrm{cd}}$ & $1.47^{\mathrm{ab}}$ & $3.3^{\mathrm{e}}$ & $42.00^{\mathrm{ab}}$ & $8.4^{\mathrm{ab}}$ & $1.97^{\mathrm{ab}}$ & $7.3^{\text {cd }}$ & $98.3^{\mathrm{ef}}$ \\
\hline G Mean & 101.17 & 13.5 & 1.47 & 4.9 & 38.97 & 8.3 & 1.94 & 5.86 & 97.1 \\
\hline SEM & 1.70 & 0.2 & 0.00 & 0.3 & 0.89 & 0.10 & 0.00 & 0.50 & 0.60 \\
\hline
\end{tabular}


In contrast, the fewest number of flowers were recorded for genotype IT 283138 with an average of 2.3 flowers. Furthermore, in the case of flower diameter, the biggest flower was found for genotypes IT 283151 and IT 283154 jointly, and the smallest flower diameters were recorded for genotype IT 283147 with an average of $18.45 \mathrm{~mm}$. The longest and shortest outer tepal were recorded for genotypes GWL 1426 (517 Sangnam) and GWL 1527 (214 Yanggu), with the average length of outer tepal $9.2 \mathrm{~cm}$ and $6.7 \mathrm{~cm}$, respectively. Likewise, the broadest outer tepal was recorded for IT 283154 within an average width of outer tepal $2.23 \mathrm{~cm}$. In comparison, the narrowest outer tepal was found for IT 283139 with an average outer tepal width of $1.60 \mathrm{~cm}$. The number of leaves burns varied from 17.3 (highest) for genotype IT 282927 to 0.3 (lowest) for genotype IT 283152. At last, for the essentia traits, days to flowering, most early flowering genotypes recorded for GWL 1522 with average days to flowering 88days while the most late-flowering genotype was IT 282927, with the average days of flowering for this genotype was recorded 107 days. The mean performance is insights that help for the selection of progeny having superior mean performance. In the line tester analysis of single crossed $F^{1}$ s. Similarly, Rai et al. (2018), has concluded that varied mean performance are possible due to the background of the genotypic variability of the studied materials.

\subsection{Heritability estimates of the investigated traits}

The details of the broad-sense heritability estimates are given in table 2 . The highest heritability estimates were obtained for days to flowering with $78.54 \%$ and while the lowest heritability estimates were obtained for leaf width with $9.96 \%$. Based on estimated heritability, it can understand that for a particular trait, there is the prevalence of strong or low levels of resemblances (Ranjan \& Gautam, 2018). Out of nine studied traits, heritability estimates obtained pointed that days to flowering had possessed mediumhigh heritability. In contrast, plant height, leaf length, number of flowers, flower diameter, length of outer tepal (OT), and leaf burn had possessed medium heritability, and leaf width and width of outer tepal (OT) had shown low heritability (Singh, 2001). According to Johnson et al. (1955), higher heritability possessed a higher estimate of GCV and GAM more critical for predicting genetic gain to ensure effective selection for improvement of any traits in the populations. This experiment is due to the prevalence of non-additive gene action of almost all traits to the phenotypic expression of traits, limiting selective breeding effectiveness.

\subsection{Genetic advance and Genetic advance as percent of the mean (GAM)}

One of the parameters in variability analysis that deserved the most vital role in determining the underlying gene action of the traits under study is considered to be the genetic advance and genetic advance as percent of the mean. According to Johnson et al.
(1955), the combined estimates of higher heritability and higher genetic gain deserved more usefulness as heritability only does not indicate the amount of genetic improvement resulting from selecting the individual genotypes. The estimated genetic advance and genetic advance as percent of the mean (GAM) are given in Table 2. Higher GAM was obtained for the traits viz. number of leaves burn, number of flowers, and flower diameter, while moderate GAM was obtained for plant weight. Furthermore, remaining traits viz. leaf length, leaf width, length of OT, the width of OT, and days to flowering were possessed a low level of GAM. Based on the practical selection and the breeding principle of Johnson et al. (1955), in this study, higher value of GCV, heritability (in a broad sense, $\mathrm{H}^{2}$ ), and GAM for the traits of the number of flowers and number of leaf burn was obtained which demonstrating that these traits were controlled by additive genetic effect and possessed heritable variability in the studied genotypes. The plant height and flower diameter are the traits that possessed a moderate value of estimated parameters, indicating the considerable improvement could be made through a compelling selection method for these traits. Furthermore, the lower combination of GCV, heritability, and GAM for the traits of leaf length, leaf width, length of outer tepal and width of outer tepal, and days to flowering proved to be the prevalence of non-additive genetic effect for these traits. There is a limitation for breeding through selection and improvement for these traits.

\section{Conclusions}

This study evaluated the variability of 30 genotypes of L. leichtlinii var maximowiczii for the 10 phenotypic traits. Investigated genotypes showed a high significance value for almost all studied traits except for leaf width, thereby revealing the prevalence of a substantial amount of genetic variability among them, which provided the experiment's validity. The number of flowers, numbers of leaf burn, plant height, and flower diameter are the traits that had possessed high and medium GCV, PCV and coupled with higher heritability and GAM confirms the effectiveness of the progeny selection breeding for these traits. On other hand, leaf length, leaf width, length of outer tepal, the width of outer tepal, and days to flowering traits demonstrated non-additive genetic effect limiting the effectiveness of progeny selection after hybridization for these traits

\section{Acknowledgements}

This study was carried out with the support of the GSP Project No. 213007-05-5-SBM10, the Ministry of Agriculture, Food and Rural Affairs, Republic of Korea.

\section{Conflict of Interest}

The authors declare that there is no conflict of interest about the content of the article. 


\section{References}

Allard RW (1960) Principles of Plant Breeding. John Wiley and Sonc Inc., New York, USA.

Burton GW, Devane E (1953) Estimating heritability in tall fescue (Festuca arundinacea) from replicated clonal material 1. Agronomy Journal 45(10):478-481.

De Jong P (1974) some notes on the evolution of lilies. Lily Yearbook 27:23-28.q.

Deshmukh S, Basu M, Reddy P (1986) Genetic variability, character association and path coefficients of quantitative traits in Virginia bunch varieties of groundnut. Indian Journal of Agricultural Sciences, 56(12):816-821.

Dhiman MR, Moudgil S, Parkash C, Kumar R, Kumar S (2018) Biodiversity in Lilium: A Review. International Journal of Horticulture 8(8):83-97.

Gao YD, Gao XF (2016) Accommodating Nomocharisin Lilium (Liliaceae). Phytotaxa 277(2):205-210.

Jeong JH (1991) Distribution and analysis of interspecific relationships in Korean native lilies. $\mathrm{Ph}$. D. Thesis submitted to the Seoul National University, Korea (in Korean with English summery).

Johnson HW, Robinson H, Comstock R (1955) Estimates of genetic and environmental variability in soybeans. Agronomy Journal 47(7)314-318.

KBIS (2013) Korea Biodiversity Information System. Available at http://www. nature.go.kr access on 28 February 2021.

Kim JH, Kyung HY, Xuan Y, Choi Y, Park YC, Hiramatsu M, Yoo KO (2004) Studies on the distribution and dispersal of Korea Lilium lancifolium Thunb. Journal of Korea Flower Research Society 12:127-141(in Korean with English summary).

Kim JH, Kyung YS, Choi YS, Lee JK, Hiramatsu M, Okubo H (2006) Geographic distribution and habitat differentiation in diploid and triploid Lilium lancifolium of South Korea. Journal of the Faculty of Agriculture, Kyushu University 51: 239-243.

Kim JH, Truong NX, Song YS, Kim NS (2016) Natural triploid Lilium leichtlinii var. maximowiczii populations in Korea. Plant Species Biology 31(2):98-106.

Kim JH, Xuan Y, Hiramatsu M, Okubo H (2005) Natural habitats and ploidy distribution of Lilium lancifolium in islands of the Bay of Kyunggi, Korea. Journal of the Faculty of Agriculture, Kyushu University 50: 593-600.
Kim TJ (2008) Wild flowers and resources plants in Korea. SNU Press, Seoul, Korea Pp. 1-5.

Lighty RW (1968) The lilies of Korea. Lily yearbook, The Royal Horticultural Society $31: 31-39$.

Lucidos JGB, Kwang R, Younis A, Kim CK, Hwang YJ, Son BG, Lim KB (2013) Different day and night temperatures responses in Lilium hansonii in relation to growth and flower development. Horticulture, Environment, and Biotechnology 54(5):405-411.

Manivannan N (2014) TNAUSTAT-Statistical Package. Retrieved from https://sites.google/site/tnaustat access on 20 July, 2021.

Matthews V (2007) The International Lily Register and Checklist. RHS London, Fourth Edition.

McRae EA (1998) Lily species. In: Lilies, A Guide for Growers and Collectors, Timber Press, Portland, Oregon. USA. pp. 239-257.

Nguyen TX, Kim JY, Rai R, Kim JH, Kim NS, Wakana A (2015) Karyotype analysis of Korean Lilium maximowiczii regal populations. Journal of the Faculty of Agriculture, Kyushu University 60(2):315-322.

Nguyen TX, Lee SI, Rai R, Kim NS, Kim JH (2016) Ribosomal DNA locus variation and REMAP analysis of the diploid and triploid complexes of Lilium lancifolium. Genome 59(8):551-564.

Noda S (1966) Cytogenetic of the origin of triploid Lilium tigrinum. Bulletin of Osaka Gakuin University, 6: 85-140 (in Japanese with English summary).

Noda S (1974) Cytogenetic relationships between Lilium tigrinum and related species, and hybrid origin of Lilium tigrinum. Lily Yearbook, North American. Lily Society 27: 98-111.

Noda S (1986) Cytogenetic behavior, chromosomal differentiations, and geographic distribution in Lilium lancifolium (Liliaceae). Plant Species Biology 1: 69-78.

Rai R, Shrestha J, Kim JH (2018) Combining Ability and Gene Action Analysis of Quantitative Traits in Lilium $\times$ formolongi. Journal of Agricultural, Life and Environmental Sciences 30:131-143.

Ranjan S, Gautam A (2018) Heritability Estimate. In: Vonk J, Shackelford T (Eds.) Encyclopedia of Animal Cognition and Behavior. Springer publication https://doi.org/10.1007/978-3-31947829-6_6-1

Singh BD (2001) Plant Breeding principles and methods. Kalyani Publishers, New Delhi, India.

Willson EH (1925) The lilies of Eastern Asia. Dulau\& Co. Ltd. London. 